\title{
IPTEKS SISTEM PENGENDALIAN INTERNAL PEMERINTAHAN PADA BADAN PERENCANAAN DAN PEMBANGUNAN DAERAH PROVINSI SULAWESI UTARA
}

\author{
Franclin Alexandria Lintang ${ }^{1}$, Syermi Mintalangi ${ }^{2}$ \\ ${ }^{1,2}$ Jurusan Akuntansi, Fakultas Ekonomi dan Bisnis, Universitas Sam Ratulangi, Jl. Kampus Bahu, Manado, \\ 95115, Indonesia \\ E-mail : franclinlintang@gmail.com
}

\begin{abstract}
Badan Perencanaan dan Pembangunan Daerah (BAPPEDA) for North Sulawesi Province is a part of regional government agency that became an element of regional government planning in helping the Governor in terms of Plan \& Execution of Regional Policies. They worked in research and planning for regional developments. In order to perform in managing its tasks and duties, BAPPEDA for Sulawesi Province has to build an internal control system within the organization, so it will promote an effective work performances in achieving BAPPEDA's visions and missions. Therefore, with the existence of Internal Government Control System that regulated on Peraturan Pemerintah No. 60 Tahun 2008 - this become the guidance for government agency in making decisions and executions; to minimize the failure possibilities in managing the organisations and agencies.
\end{abstract}

Keywords : Government, Internal Control System, Bappeda Sulut

\section{PENDAHULUAN}

Demi mewujudkan serta meningkatkan efisiensi dan ekeftivitas dalam Instansi Pemerintahan atau Satuan Kerja Perangkat Daerah (SKPD) diperlukan penerapan pengendalian internal yang baik untuk mewujudkan tujuan dari Instansi tersebut. Dalam hal ini di Indonesia, diperlukan suatu sistem sehingga dalam melaksanakan tugas dan fungsi Instansi dapat diukur seberapa besar tingkat pencapaian kinerja yang telah dilakukan. Sehubungan dengan pengendalian intern di Indonesia, maka Pemerintah dalam menjanlankan tugas penyelenggaran Negara serta mengatur alur proses penyelenggaran Negara harus membangun Sistem Pengendalian Intern yang dimana, pihak Pemerintah dapat mencegah dan menimalisir terjadinya kegagalan sistem pengelolaan pada instansi pemerintahan.

Salah satu bagian Satuan Kerja Perangkat Daerah (SKPD) yang perlu juga melaksanakan dan menetapkan Sistem Pengendalian Internal Pemerintah (SPIP) yaitu, BAPPEDA Sulut. BAPPEDA Sulut menjadi unsur perencanaan penyelenggara pemerintahan daerah yang juga mempunyai tugas membantu Kepala Daerah dalam hal ini Gubernur untuk menyusun dan melaksanakan kebijakan di bidang penelitian dan perencanaan pembangunan daerah, serta memiliki wilayah kerja seluruh Kabutan/Kota dan Provinsi yang ada di Sulawesi Utara. Dalam menjalankan tugas dan fungsi, BAPPEDA Sulut telah menetapkan pengendalian internal dalam lingkup kerjanya sendiri, sehingga dalam mencapai visi dan misi dari BAPPEDA Provinsi Sulawesi Utara dapat terwujud dan terlaksanakan dengan baik. Sehingga Sistem Pengendalian Pemerintah yang diatur dalam PP No. 60 Tahun 2008 dapat terlaksanakan. Dalam hal tersebut juga terdapat elemen-elemen pengendalian intern yaitu lingkungan pengendalian, penilaian risiko, kegiatan pengendalian, informasi dan komunikasi dan pemantaun pengendalian intern, yang menjadi tolak ukur organisasi dalam melakukan tindakan. 


\section{TINJAUAN PUSTAKA}

Sistem Pengendalian Internal Pemerintah. Sistem Pengendalian Internal Pemerintah (SPIP) adalah proses yang integral pada tindakan dan kegiatan yang dilakukan secara terus-menurus oleh pimpinan dan seluruh pegawai. (Dadang \& Dalibas, 2014).

Elemen Sistem Pengendalian Pemerintah. Dalam buku Mahmudi (2011:253) Sesuai dengan Peraturan Pemerintah No. 60 Tahun 2008 tentang Sistem Pengendalian Internal Pemerintahan terdiri dari: lingkungan pengendalian, penilaian risiko, kegiatan pengendalian, informasi dan komunikasi, dan pemantauan pengendalian intern.

\section{METODE DAN TEKNIK PENERAPAN IPTEKS}

\subsection{Metode Penerapan Ipteks}

Metode ipteks yang diterapkan adalah mengimplementasikan pengendalian internal menurut PP No. 60 Tahun 2008 pada Badan Perencanaan dan Pembangunan Daerah Provinsi Sulawesi Utara.

\subsection{Teknik Penerapan Ipteks}

Melalui penelitian yang dilakukan, diterapkan tek nik ipteks yaitu melakukan pengamatan terhadap pengendalian internal yang dilakukan menurut Peraturan Pemerintah Republik Indonesia No. 60 Tahun 2008 yang menyangkut hal: lingkungan pengendalian, penilaian risiko, informasi dan komunikasi dan pemantaun pengendalian intern.

\section{PEMBAHASAN}

\subsection{Gambaran Objek Penerapan Iptek}

BAPPEDA Provinsi Sulawesi Utara merupakan badan milik pemerintah, yang dalam kepemimpinannya dikepalai oleh Kepala Badan yang melaksanakan dan mengemban amanat dari Kepala Daerah Provinsi maupun Kab/Kota, dalam bidang Perencanaan Pembangunan Daerah serta berperan untuk menyusun dan melaksanakan kebijakan Daerah.

Melalui Permendagri No. 86 tahun 2017 menyangkut tugas, fungsi, dan tujuan BAPPEDA Sulut, yaitu dalam mewujudkan pembangunan Daerah dalam rangka meningkatan serta pemerataan pendapatan masyarakat, kesempatan kerja, lapangan kerja, peningkatan fasilitas dan layanan publik yang layak, serta daya saing Daerah.

\subsection{Pembahasan}

Dalam mewujudkan suatu tatanan yang sesuai dan terintegrasi pada instansi pemerintahan diperlukan sistem, yang dimana berhubungan dengan pengendalian intern sehingga memungkinkan dan dapat meminimalisir kegagalan pengelolaan. Maka pihak instansi pemerintahan harus menjalankan Elemen SPIP yang terdiri atas unsur:

Lingkungan Pengendalian. Dalam membangun sistem sebaiknya meneliti kembali lingkungan kerjanya. Lingkungan dalam pengendalian diperlukan untuk membangun individual yang dapat melaksanakan tugas-tugasnya berdasarkan keahlian, keteladanan terhadap aturan, serta mampu berpikir kritis dalam menanggapi lingkup kerjanya. Sehingga sistem harus dibuat mengikuti prosedur yang telah ditetapkan dalam organisasi berdasarkan visi dan misinya, sebagus apapun sistem pengendalian yang dibuat jika ada oknum tertentu, yang ada didalamnya tidak sesuai dengan bidang pekerjaannya dan melakukan penyimpangan dari sistem yang dibuat, maka merusak sistem yang dibangun, sehingga berpengaruh juga dalam tujuan organisasi. Membangun hubungan yang baik juga perlu dilakukan Bappeda Provinsi Sulawesi Utara antara pejabat struktural dan fungsional serta tenaga harian lepas (THL) maupun pihak luar (eksternal) dalam hal ini mitra kerja dari tiap bidang dalam Bappeda. Untuk itu Bappeda sebagai unsur perencanaan penyelenggara pemerintahan daerah dalam hal ini di Provinsi Sulawesi Utara, perlu menyadari akan pentingnya unsur ini dalam hal melakukan pengendalian intern, sehingga dapat melaksanakan tugas dan fungsinya sesuai dan tidak melakukan penyimpangan dengan peraturan-peraturan yang ada. 
Penilaian risiko. Memberikan penilaian mengenai risiko apa yang akan terjadi dan yang harus dihadapi. Untuk itu dalam penilaian risiko Bappeda Provinsi Sulawesi Utara, terkait bidang perencanaan dan pembangunan Daerah harus mengidentifikasi dan menganaslisis risiko apa yang akan timbul pada kedepannya, sehingga program kerja yang telah dibuat oleh Bappeda Provinsi Sulawesi Utara dapat teralisasi dengan baik.

Kegiatan Pengendalian. Kegiatan pengendalian merupakan suatu proses perencanaan pembangunan dengan tujuan untuk perubahan menuju perkembangan pembangunan yang lebih baik bagi masyarakat dan pemerintah dalam wilayah tertentu dengan memanfaatkan sumber daya yang ada dengan orientasi secara menyeluruh, lengkap dan perpegang pada asas prioritas. Dengan tugas dan fungsi yang ditanggungkan oleh kepala daerah terhadap BAPPEDA tentunya membutuhkan sesuatu membantu dalam rangka peningkatan keuntungan secara maksimal baik sisi waktu maupun kualitas. Sistem untuk perencanaan pembangunan daerah (E- Planning) merupakan alat yang digunakan untuk membantu menyusun Rencana Kerja Pemerintah Daerah, kebijakan umum anggaran, prioritas plafon anggaran sementara, KUA PPAS Perubahan, RKPD Perubahan dari instansi pemerintahan di kabupaten supaya dapat terselesaikan dengan tepat, mudah dan cepat serta sesuai dengan yang tercantum dalam Peraturan Menteri Dalam Negeri No. 54 Tahun 2010. Dengan diaplikasikannya E- Planning, BAPPEDA dapat meningkatkan sistem serta mampu menghasilkan analisa yang informatif bagi pihak yang berkepentingan, sehingga dapat meminimalkan unsur-unsur penilaian resiko.

Informasi dan Komunikasi. Infomasi yang akurat dan komunikasi yang baik antar atasan maupun bawahan begitu juga bawahan pada atasannya mempengaruhi jalan atau alur informasi dan komunikasi sendiri, Baik halnya juga pada Bappeda Provinsi Sulawesi Utara, perlu ada hubungan yang antara atasan dan bawahan sehingga pengkomunikasian dapat terjaga serta alur informasi yang ada dapat tersampaikan sebagaimana mestinya pada pimpinan instansi atau pihak lain yang memiliki keterkaitan kerja. Sehingga dapat dilaporkan dan diolah secara efektif dan efisien, serta pimpinan instansi dapat mengambil keputusan yang tepat dan melakukan tanggung jawabnya sebagaimana mestinya.

Pemantaun Pengendalian Intern. Dengan melakukan pemantauan Bappeda Provinsi Sulawesi dalam hal ini dapat mengukur kinerja yang telah dicapai apakah meningkat atau menurun dibandingkan dengan instansi pemerintah lain, sehingga dalam kedepannya Bappeda Provinsi Sulawesi Utara mempunyai tolak ukur atau acuan atas kinerjanya.

\section{KESIMPULAN DAN SARAN \\ 5.1 Kesimpulan}

BAPPEDA Prov. Sulut dalam melaksanakan tugas dan fungsinya, akan tercapai jika pihak-pihak yang ada didalamnya mampu menyesuaikan serta menjalankan elemen SPIP dalam instansi pemerintahan beserta unsur yang mengkaji pengendalian internal dalam intansi pemerintahan.

\subsection{Saran}

Perlu adanya kesadaran yang tinggi serta relasi yang baik antara pihak organisasi atau instansi pemerintah dan pihak internal maupun eksternal dalam membangun sistem pengendalian dalam lingkungan kerjanya. Diharapkan untuk kedepannya BAPPEDA Prov. Sulut mampu meningkatkan lagi sistem pengendaliannya sehingga mampu menjadi contoh pada instansi lain dalam menjalankan tugas dan fungsi sebagaimana mestinya.

\section{DAFTAR PUSTAKA}

Kementrian Dalam Negeri Republik Indonesia. 2017. PERMENDAGRI Nomor 86 Tahun 2017 Tentang Tata Cara Perencanaan, Pengendalian Dan Evaluasi Pembangunan Daerah, Tata Cara Evaluasi Rancangan Peraturan Daerah Tentang Rencana 
Pembangunan Jangka Panjang Daerah Dan Rencana Pembangunan Jangka Menengah Daerah, Serta Tata Cara Perubahan Rencana Pembangunan Jangka Panjang Daerah, Rencana Pembangunan Jangka Menengah Daerah, Dan Rencana Kerja Pemerintah Daerah. Jakarta

Pemerintah Republik Indonesia. 2008. Peraturan Pemerintah No. 60 Tahun 2008 tentang Sistem Pengendalian Internal Pemerintahan.

Peraturan pemerintah Republik Indonesia nomor 71 tahun 2010 tentang standar akuntansi pemerintahan

Mahmudi, 2011. Akuntansi Sektor Publik. Yogyakarta: UII Press Yogyakarta (Anggota IKAPI).

Mardiasmo, 2009. Akuntansi Sektor Publik Edisi IV. Yogyakarta: C.V ANDI OFFSET.

Dalibas, S. Dadang. 2014. Sistem Pengendalian Intern Pemerintah. Indonesia: PPM.

Kementrian Dalam Negeri Republik Indonesia. 1980. Keputusan Mendagri Nomor 185 tahun 1980, tentang Pedoman Organisasi dan Tata Kerja Badan Perencanaan Pembangunan Daerah Tingkat I dan Badan Perencanaan Pembangunan Daerah Tingkat II. Jakarta

Pratiwi, W. (2012) “Analisis Penerapan Sistem Pengendalian Intern: Studi Kasus Pemerintah Kabupaten Bungo”. Jurnal Ekonomi STIE Haji Agus Salim Bukittinggi, XII(2), 82103.

Susilawati dan Riana, D.S. 2013. Standar Akuntansi Pemerintahan dan Sistem Pengendalian Intern sebagai Anteseden Kualitas Laporan Keuangan Pemerintah Daerah. Jurnal STIE STEMBI Bandung. Kapoh, Octaviani M., Ilat, Ventje., Warongan, Jessy D.L., 2017. Analisis Pelaksanaan Sistem Pengendalian Internal pada Inspektorat Kabupaten Minahasa Utara. Jurnal Riset Akuntansi Going Concern Vol. 12 No.2. Universitas Sam Ratulangi. Manado

BAPPEDA SULUT, e-planning [Online] http://bappeda.sulutprov.go.id/e-planning/. Tanggal akses 31 Oktober 2018.

BAPPEDA SULUT, Tugas Pokok dan Fungsi [Online] http://bappeda.sulutprov.go.id/tugaspokok-dan-fungsi/. Tanggal akses 31 Oktober 2018.

Sugijanto.2002. Peranan Sistem Akuntansi Pemerintah Pusat Dalam Meningkatkan Akuntabilitas Keuangan dan Implikasi UU No. 22/25 Tahun 1999.Lintasan Ekonomi.Volume XIX Nomor 1.Hal. 50-66

Bodnar, H.G. dan Hopwood, W.S. 2010. Sistem Informasi Akuntansi. Buku I. Edisi Ke-6. Penerjemah Amir Abadi Jusuf dan Rudi M. Tambunan. Jakarta: Salemba Empat

Hasmah, Ridha, 2010, Menyongsong Penerapan Sistem Pengendalian Intern Pemerintah (SPIP) : Menuju Tata Kelola Pemerintahan Yang Baik, Majalah Perencanaan Pembangunan, Edisi 03, hal 21-24 